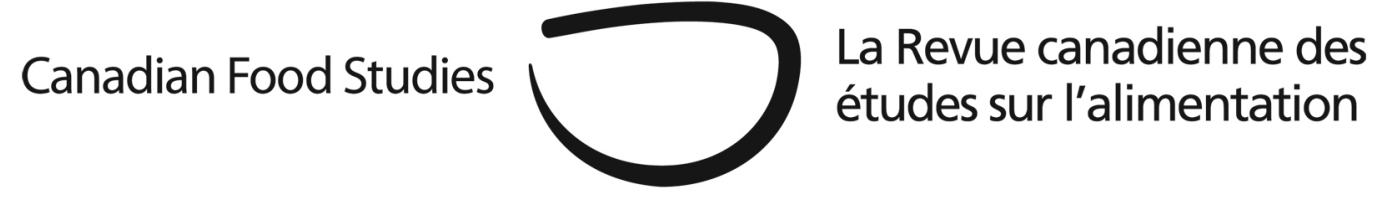

Commentary

\title{
A food policy for Canada, but not just for Canadians: Reaping justice for migrant farm workers
}

Anelyse M. Weiler

University of Toronto

\begin{abstract}
In this policy commentary, I highlight opportunities to advance equity and dignity for racialized migrant workers from less affluent countries who are hired through low-wage agricultural streams of Canada's Temporary Foreign Worker Program. Core features of the program such as 'tied' work permits, non-citizenship, and workers' deportability make it risky for migrant farm workers to exercise their rights. I discuss five federal policy interventions to strengthen justice for migrant farm workers in Canada: 1) permanent resident status; 2) equal access to social protections; 3) open work permits; 4) democratic business ownership; and 5) trade policy that respects community self-determination. To realize a food system that enables health, freedom and dignity for all members of our communities, a Food Policy for Canada cannot be for Canadians alone.
\end{abstract}

Keywords: food policy, migrant workers, Canada 


\section{Introduction}

The abundance of food in Canada has long hinged on the labour of people who are denied the bundle of rights that come with Canadian citizenship. Industries such as meatpacking, fast-food, and fish-processing hire migrant workers from poorer countries through Canada's Temporary Foreign Worker Program. As a result of racialized global inequality, migrant workers often face pressure to accept the wages, working, and living conditions at hand (Binford, 2013). Canadian workers generally have greater power to refuse such employment. To realize a food system that enables health, freedom, and dignity for all members of our communities, a Food Policy for Canada cannot be for Canadians alone.

This policy commentary focuses on one part of Canada's low-wage migrant workforce: farm workers. Canada's treatment of migrant farm workers has attracted international concern. Following his visit to Canada, Olivier de Schutter (2012), United Nations Special Rapporteur on the Right to Food, critiqued the country's temporary farm worker regime: "In short, a marginalized category has been created essentially in order to compensate for the increased concentration in the farming sector and for the failure to ensure that farming remains attractive to Canadians” (p.9). I begin by outlining how Canada’s migrant farm worker regime places workers in highly exploitable positions. Five federal policy interventions are proposed for a national food policy to ensure migrant farm workers in Canada have equal access to the material stuff of life, social recognition, and a political voice.

\section{How Canada's labour-migration scheme undermines workers' rights and dignity}

Initiated in 1966, the Seasonal Agricultural Worker Program (SAWP) allows employers to hire farm workers from Mexico and Caribbean Commonwealth countries for up to eight months (Binford, 2013). The SAWP is driven by employers' labour demands and based on bilateral agreements between Canadian and sending-country governments. Since 2002, employers have been permitted to hire workers through additional agricultural streams of the overarching Temporary Foreign Worker Program. These latter streams do not involve bilateral agreements and employ workers from any country for up to 24 months (Nakache \& Dixon-Perera, 2015). Canada's migrant farm worker arrangement has continued to expand rapidly; the number of migrant farm workers hired through the SAWP and related streams grew from approximately 35,000 in 2008 to approximately 53,000 in 2015 (ESDC, 2016).

For a migrant farm worker to maintain their immigration status in Canada, they must remain employed by the person who hired them (Binford, 2013). If they encounter poor employment conditions, switching farms is often tricky. Workers also depend on employers to give them a positive evaluation and nominate them to return the following year. Migrant workers can labour each season for decades in Canada without a formal way of gaining permanent residency and settling in Canada with their families. The preferential recruiting and hiring of 
men has resulted in stark gender inequity among migrant farm workers (Preibisch \& Encalada, 2013). While migrant workers' motivation for working in Canada is often to provide a better life for their loved ones, prolonged separation can tear their families apart (Díaz Mendiburo, Lyn, McLaughlin, Vasilevska, \& Wells, 2017).

Earning a higher wage in Canadian currency consistently comes at a high cost to migrant farm workers. Some of the systemic problems workers repeatedly report include substandard housing and transportation, employer expectations of extreme productivity, and a lack of control over workplace hours (Binford, 2013; Reid-Musson, 2017). Barriers to health care loom especially large. For example, in 2013 Jamaican SAWP worker Robert Sulph was working on an Ontario tobacco farm when a blade flew off a metal cutter, slicing open his neck and leaving him with a life-threatening injury (Mojtehedzadeh, 2016). Although Sulph was supposedly entitled to full compensation under provincial law, he had to pay for his medical expenses up front and was cut off of workers' compensation after just twelve weeks. Migrant workers' deportability undermines their ability to exercise the rights to which they are theoretically entitled, and it makes it dangerous for them to speak up.

\section{Policy solutions}

Researchers have identified a suite of policies for all levels of government to ensure justice for migrant farm workers in Canada (Fairey et al., 2008; Faraday, 2008; Hennebry \& McLaughlin, 2011). Provincial governments can ensure livable wages, full protection under employment standards (including union legislation), proactive legislation to prevent extortion by private recruiters, and random spot-checks for workplaces and housing. At the federal level, five core opportunities for policy intervention include:

1. Immigration: A precarious immigration status underlies many of the systemic inequities migrant farm workers face. While some industry actors have championed a two-step 'pathway' to permanent residency, research on hog-processing workers in Manitoba demonstrates this twostep process can intensify the unequal power dynamic between migrant workers and employers (Bucklaschuk, 2016). Instead, workers and advocates have called for permanent resident status on arrival for all migrant workers.

2. Social Protections: Migrant workers’ wages are automatically deducted for federal social benefits (Ramsaroop, 2016). Because migrants often cannot access those benefits, they are effectively subsidizing Canada's social benefits system. Migrant farm workers should have full coverage under those programs. This includes restoring eligibility for full Employment Insurance benefits, which were partly stripped away by the Harper government in 2012. 
3. Open Work Permits: Shifting from tied work permits to open work permits would enable migrant farm workers to leave problematic workplaces more easily and would reward high-road employers.

4. Ownership: While respecting Indigenous sovereignty and land restitution, a national food policy for Canada can provide a framework to promote the democratic ownership of some farmland and farming businesses, including worker-owned cooperatives. It can also support modes of farming that allow workers to express their knowledge and skills through a diversity of activities, rather than a division of labour based merely on menial, hyper-specialized tasks.

5. Trade Policy: Canada's national food policy must address the context of poverty and unemployment that often drives many people of colour from less affluent countries to seek work abroad. This includes Canada's complicity in trade liberalization processes such as the North American Free Trade Agreement that have undermined livelihood self-determination in Mexico (Otero, 2011). Current policy choices have boosted the power of corporate agribusiness and supermarket retail chains to shape food prices, which undermines not only small and mediumscale farmers, but also hired workers.

\section{Conclusion}

What does the future hold for migrant farm workers? Climate change will likely have a profound effect on agriculture both in Canada and in migrant farm workers' countries of origin. Given the country's significant contribution to anthropogenic climate change, Canada bears an obligation to welcome current and future people who are displaced by climate change, and not simply to extract their labour. Ultimately, food security in Canada cannot occur on the backs of migrant farm workers, their families and home communities (Weiler, McLaughlin \& Cole, 2017). A national food policy must ensure that all those engaged in the vital work of producing food and other agricultural products are granted respect and the material means to thrive.

Acknowledgment: The author has received research support from the Social Sciences and Humanities Research Council of Canada Joseph Armand-Bombardier Scholarship, and a 2015 scholarship from the Pierre Elliott Trudeau Foundation.

\section{References}

Binford, L. (2013). Tomorrow we're all going to the harvest: Temporary foreign worker programs and neoliberal political economy. Austin, TX: University of Texas Press. 
Bucklaschuk, J. (2016). A temporary program for permanent gains? Considering the workplace experiences of temporary foreign workers in Manitoba's hog-processing industry. In S. A. McDonald \& B. Barnetson (Eds.), Farm workers in Western Canada: Injustices and activism (pp. 101-119). Edmonton, AB: University of Alberta Press.

De Schutter, O. (2012). Mission to Canada. Retrieved from http://www.srfood.org/images/stories/pdf/officialreports/20121224_canadafinal_en.pdf

Díaz Mendiburo, A., Lyn, A., McLaughlin, J., Vasilevska, B., \& Wells, D. (2017). Sacrificing the family for the family: Impacts of repeated separations on temporary foreign workers in Canada. In S. Procyk, W. Lewchuk, \& J. Shields (Eds.), Precarious employment: Causes, consequences and remedies. Winnipeg, MB: Fernwood Publishing.

ESDC. (2016). Annual Labour Market Impact Assessment Statistics 2008-2015: Primary Agriculture Stream. Retrieved from https://www.canada.ca/en/employment-socialdevelopment/services/foreign-workers/reports/2014/lmia-annual-statistics/agricultural.html

Fairey, D., Hanson, C., MacInnes, G., McLaren, A. T., Otero, G., Preibisch, K., \& Thompson, M. (2008). Cultivating farmworker rights: Ending the exploitation of immigrant and migrant farmworkers in BC. Canadian Centre for Policy Alternatives. Retrieved from https://www.policyalternatives.ca/sites/default/files/uploads/publications/BC_Office_Pubs/ bc_2008/bc_farmworkers_full.pdf

Faraday, F. (2014). Profiting from the precarious: How recruitment practices exploit migrant workers. Metcalf Foundation. Retrieved from http://metcalffoundation.com/wpcontent/uploads/2014/04/Profiting-from-the-Precarious.pdf

Hennebry, J., \& McLaughlin, J. (2011). Key Issues \& Recommendations for Canada’s Temporary Foreign Worker Program: Reducing Vulnerabilities and Protecting Rights. International Migration Research Centre. Retrieved from https://legacy.wlu.ca/documents/44257/IMRC_Policy_Points_Issue_II__Recommendations_for_Canada\%5C_s_Foreign_Worker_Program.pdf

Mojtehedzadeh, S. (2016, March 21). Migrant farm worker launches discrimination complaint against WSIB. Toronto Star. Retrieved from https://www.thestar.com/news/gta/2016/03/21/migrant-farm-worker-launchesdiscrimination-complaint-against-wsib.html

Nakache, D., \& Dixon-Perera, L. (2015). Temporary or transitional? Migrant workers' experiences with permanent residence in Canada. Institute for Research on Public Policy. Retrieved from http://irpp.org/research-studies/study-no55/

Otero, G. (2011). Neoliberal globalization, NAFTA, and migration: Mexico’s loss of food and labor sovereignty. Journal of Poverty, 15(4), 384-402.

Preibisch, K., \& Encalada, E (2013). Between hearts and pockets: Locating the outcomes of transnational homemaking practices among Mexican women in Canada's temporary migration programmes. Citizenship Studies, 17(6-7), 785-802. 
Ramsaroop, C. (2016). The case for unemployment insurance benefits for migrant agricultural workers in Canada. In A. Choudry \& A. Smith (Eds.), Unfree labour: Struggles of migrant and immigrant workers in Canada (pp. 105-122). Oakland, CA: PM Press.

Reid-Musson, E. (2017). Grown close to home ${ }^{\mathrm{TM}}$ : Migrant farmworker (im)mobilities and unfreedom on Canadian family farms. Annals of the American Association of Geographers, 107(3), 716-730.

Weiler, A. M., McLaughlin, J., \& Cole, D. C. (2017). Food security at whose expense? A critique of the Canadian temporary farm labour migration regime and proposals for change. International Migration, 55(4), 48-63. 